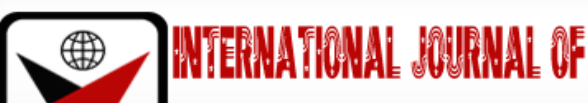

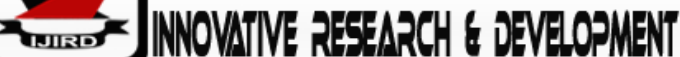

ISSN 2278-0211 (Online)

\section{Communal Conflicts and Agricultural Development Programmes Implementation in the North-East Geo-political Zone of Nigeria}

\begin{tabular}{|c|}
\hline Omini Ubi Ubi \\
Assistant Lecturer, Department of Public Administration, \\
University of Calabar, Nigeria \\
Friday O. Iyanam \\
Assistant Research, Department of Defense and Security, \\
Institute for Peace and Conflict Resolution, Abuja, Nigeria
\end{tabular}

\begin{abstract}
:
This article views communal conflicts which are capable of hindering agricultural development programmes from implementation in the North-East Geo-Political Zone of Nigeria. The region is bedeviled with series of protracted communal conflicts, ranging from herders-farmers' bloody clashes, political conflicts, religious conflicts, ethnic conflicts and the Boko Haram crisis. These conflicts have affected the growth and development of the region and a spillover in Nigeria. The article ventures and explore the possible causes of communal conflicts, highlights the agricultural programs in the region and the solutions which centers on government intervention with the appropriate machineries and policies in order to put an end to this bloody conflict with the aim to strengthen the economic activities and development in the region, Nigeria and Africa in general. Conflict theory was used to explain the article.
\end{abstract}

Keywords: Communal conflicts, north-east geo-political zone, Nigeria, agricultural development programmes

\section{Introduction}

Communal conflict has been very common in the African societies and the result of these conflicts is bloody calamity in the aspect of destruction of lives, property, livelihood and hindrance to economic development. According to Oji, Eme and Nwoba (2014), conflict generally is the reality of social relations. While Otite (2001), posit that conflicts at any sphere arise from divergences of interests, desires, goals and values aspirations in the competitiveness for resources to meet up with imposing demands on social life in a clearly stated socio-physical environment. As far as man existence continues conflicts would definitely abound as a result of the struggle for national resources.

According to Oji, Eme and Nwoba (2014), conflicts constitute one of the major recurring problems affecting the socio-political landscape of Africa. Communal conflicts are as old as man and it is taking new dimension in contemporary times considering the fact that the weapons used are highly sophisticated and the destruction is usually fatal. Pre-colonial and colonial Nigeria experienced inter-kingdom dynastic crises and inter-community conflicts (Ogban-Iyam, 2005). In recent times numerous Nigeria's communities have witnessed series of conflicts. The ones that are renowned and with high level of loss of lives and destruction of properties are the Zango-Kataff conflict in Kaduna State (1999-2000); the TIVJukun - Wakari conflict in Taraba State (1999-2001); the Itsekiri - Urhobo Warri conflict in Delta State, (1999-2001), Mangu-Bokoss conflict (1988-1999); the Ife- Modakeke Crisis (1999-2000); (Otite, et al, 1999; Imobighe et al., 2002, Ubi 2001; Omatayo, 2005; Best 2007). The people who are involve in these conflicts used to carry dangerous arms to attack one another and this is very devastating to the country whose pathway is on development. The various conflicts mentioned above are just few in the view of the conflicts that had occurred from 2005-2021 in many states of the Federation.

Apart from the crisis mentioned, the African continent is riddled with conflicts of various kinds, these conflicts range from election disputes, resource and environmental issues, civil war, armed insurgency, religious intolerances, ethnic chauvinism, community and boundary conflicts between countries (Matthew, 1970; Wood 1993; Obi, 1999; Idowu, 1999; Blanton et al., 2001; Adejumbi, 2001; Rwantabgu 2001; Ukino, 2003; Allen and Okeke-Uzodike, 2010; Agbu, 2004; Ghana, 2005-2006; Moritz, 2006; Ibaba, 2007, 2011; Ayai, 2009; Alozienwa, 2010; Amugwa, 2011; Uhumwangho, 2011). These conflicts are responsible for the crawling and poor state of the African economy and the continuous dependence on the developed countries for financial assistance. One thing that is very peculiar about conflict is the aftermath effect. In Henry (2017) view on the aftermath of the Nigerian Civil War was that, memories of the destructive effects of the bloody war was responsible for the formation of pressure groups in the South-East Geo-political zone, such as the Movement of 
the Actualization of the Sovereign state of Biafra (MASSOB) and the Indigenous People of Biafra (IPOB). These groups have been agitating for their own country as they still perceived injustice by the Nigerian government.

This article is limited to communal conflicts and agricultural development programmes implementation in the North-East Geo-Political Zone of Nigeria. At present, the North Eastern States in Nigeria is characterized with serious conflicts. The Nigerian government have been engaging the insurgents for almost a decade. This Boko-Haram conflict has a very serious toll on the agricultural implementation programmes of the geo-political zone. In line with Onwusiribe et al (2015) stated that, insurgency or conflict the world over has taken a heavy toll on the quality and quantity of food that people require for better living. This is the case with the North-Eastern States in Nigeria. The states that fall under these zones are Bauchi, Yobe, Gombe, Adamawa, Borno and Taraba. These states have their peculiar conflicts. In Borno State, there is Boko-Haram crisis which is seriously draining the resources of Federal government. Yobe state is not left out in the series of suicide attacks from the dreaded book-haram and political crisis. Gombe too is prone to terrorist attacks and herders and farmer clashes. Adamawa and Taraba states are flash points for incessant bloody mayhem of farmers and herders, religious and ethnic conflicts. In fact, the herder bloody crisis has a source of international concern as they kill and raid villages with impunity. Alhassan (2013) outlined that Fulani herdsmen and farmers conflict have remained the most predominantly resource use conflict in North-Eastern Nigeria especially in Yobe state. The state seems to be hapless in combating this Fulani and farmers clashes. The failure of the state, for instance to resolve the settler/indigene identity and the continuous struggles over resources can be adduced to have brought dangerous dimension of economic and political elements in the Fulani pastoralists and farmers' conflict (Fiki and Lee, 2004)

\section{Literature Review}

\subsection{Causes of Communal Conflicts in Nigeria}

Ilvento (1995), in his examination of communal conflict mentioned the importance of components like place, people inhabit a geographical area and work together in turn which give opportunity for interaction, which engender conflict. Succinctly, the ubiquity of modern communication technology has not replaced the fundamental relation between propinquity and interaction. To follow suit, Mullin (1990) states that conflict in any social system is the result from differences in thinking, limited resources, role conflict, inequitable treatment, violation of territory etc. Communal conflict arises over the production and consumption of goods, socialization, social control and social participation (Warren, 1978). While Alhassan (2013) posits that when the state cannot regulate the mutual coexistence of its citizens in a harmonious sharing of the competitive resources, the people may have to resort to struggle among themselves with no retreat, no surrender and for the survival of the fittest. In this regards Fiki and Lee (2004) maintained that the failure of the state, for instance to settle the settler/indigene identity and the inherent struggles over resources can be adduced to have brought dangerous dimensions of economic and political elements in the Fulani pastoralists and farmers conflict.

Since there is no smoke without fire, likewise there are causes of communal conflict in Nigeria. Religion is always an issue in Nigeria, mostly between Christians and Muslims in the Northern part of Nigeria and a reprisal attack in the South. The problem of religion is a big issue in Nigeria. Boko-Haram insurgent are fighting for religion, they term to see western education as forbidden and carrying out serious onslaught against educational institutions and public infrastructures. The return of democracy in 1999 in Nigeria saw some governors in Northern part of Nigeria introduced the Sharia law which is already embedded in the constitution of the Federal Republic of Nigeria. The enforcement of Sharia law in the North faced resistance by Christians since they were forced to obey Sharia. This resistance led to the death of many persons. Similarly, there were series of religious crises in Jos, Plateau State, Bauchi, Taraba and Yobe. The problem of religion is not only a Nigerian issue; it is a global problem. Iraq, Iran, Pakistan, India, Palestine and Afghanistan among others had their share of religious conflicts.

Apart from inter-religious crisis, there is inter-religious problem too in Nigeria. Among the Christian community the doctrine and order of workshop are practically different and this has caused serious crises. The Islamic faith also are experiencing such, lately the Shia Islamic Movement of Nigeria have been having issues with some Northern Government. The Shia Movement seems to be resisting the government of their host states according to their faith. The movements also have issues with the Nigerian Army. At present the leader EL Zazaki is still in detention. This Islamic movement differs in worship with the regular Muslims.

There is the cultural aspect as another cause of communal conflict. Oji, Eme and Nwoba (2014) explained that, tradition and culture have been discovered as major conflict triggers, and transformers. Otite (2001), notes that the world of ancestors is seen as an extension of the world of the living and that supernatural beings are part and parcel of the Nigerian system of thought. In the study of Tiv-Jukun conflicts Best, et al (2001) revealed that the Tiv has the largest ethnic group in the Middle Belt Region of Nigeria were about to gain strong foothold in numerous communities in the area because of their languages and culture permeated other culture thereby altering the sociology of those communities. According to Echiagu (1999), states that, the settlement arrangement of the Ezzas and their war-like behavior led to the invasion of the sub-neighboring sub-ethnic groups.

Land dispute communal crisis is a very common cause in Nigeria. Several researchers revealed that most of the communal conflicts in Africa and Nigerian communities are linked to land scarcity, territorial disputes and competition for the use of land. Dummoye (2003) in a survey of conflicts in the Middle Belt Zone of Nigeria linked the cause of communal conflict to land scarcity and boundary disputes, due to population explosion, alienation and concentration.

In Northern Nigeria, the farmers and herders conflict is more renowned. For Ega and Erhabor (1999), reported that the key underlying causes of farmers and herdsmen conflict in Nigeria is particularly severe on the traditional trek routes, which become favorite cropping sites because of their better soil fertility resulting from this is exacerbated by the 
fragmented nature of the crops plots which animals from raying in the crop plots absolutely difficult. These are just few of what could propel communal conflicts in Nigeria.

\subsection{Conflict Theory}

The conflict theory views the society as characterized with competition for limited resources. The perspective is a macro level approach most linked with the German Philosopher and Sociologist, Karl Marx (1818-1883) who visualized the larger society as being made up of individuals in various social classes who must compete for social, material and political resources such as food, housing, employment, education and leisure time. Social institutions like government, education and religion reflect the competition in their inherent inequalities and help maintain the unequal social structure. Individuals and groups in organizations are able to obtain and keep more resources than others and these people use their power and influence to maintain social institutions.

The conflict in North East Nigeria involve farmers and herders clash which has claimed much lives and properties. While the farmers do not move with the land where their crops are planted, the herders move from one place to another with their cattle to feed on crops and drink water. The cow feed on the crops which the herders believe the land belongs to God, thus their cattle can feed. In the event of these herders destroying farmlands this has often resulted to bloody clashes. The religious conflicts as regards to Muslims and Christians are almost a yearly occurrence. Ethnic conflicts, political conflicts and land disputes have crippled agricultural activities and other developmental projects that would have propelled socio-economic development of the area. The fight against Boko-Haram terrorists by the Nigeria Military have been waging for a decade now and the war seems unending soon. Boko Haram terrorists want the people of the region to avoid western education and embrace their own version of Islam which forbids western education.

Therefore, since conflict have dwindled development, the government of Nigeria should step into it urgently to resolve the herders and farmers conflict permanently by making appropriate policies to curtail the movement of nomadic herdsmen with their intention to feed on crops and destroy farmlands. Rather, modern ranching should be embraced with all alacrity. While political, religious and ethnic conflicts should also be speedily resolve to avoid deeper hate, rather promote tolerance, peace and justice. The Federal Government of Nigeria should begin to use the law to punish trouble makers to serve as deterrent to others. The case of Boko Haram has reached an international dimension, thus the Nigerian government should as a matter of urgency seek for international intervention from the United Nation in order to put an end the murderous and nefarious activities of Boko Haram. This would further restore development and strengthen the economic activities of the region, thereby stimulating growth to other regions and Africa in general.

\subsection{Agricultural Development Programmes in the North East Geo-Political Zone of Nigeria}

The six states that make up the North East Geo-Political Zone are Adamawa, Borno, Bauchi, Gombe, Yobe and Taraba, these states are prone to communal conflicts such as farmers against herders, religious conflict and insurgency among others. For Alhassan (2003), the states cannot regulate the mutual coexistence of its citizens in the harmonious sharing of the competed resources, the parties would have to struggle among themselves with no retreat, no surrender and for the survival of the fittest.

This essence of this article was to view some agricultural development programmes in the North East Zone of Nigeria. Agriculture used to be the main stay of Nigerian economy before the advent of oil in commercial quantity. Although with huge revenue from oil, the agricultural sector has not been receiving the desired government attention in terms of the best agricultural policies. But the sector is very crucial to the development of the Geo-Political Zone in particular and Nigeria in general. If the agricultural sector is neglected or the conflict disrupting the smooth implementation of agricultural programmes, there is bound to be food insecurity and narrowing of the economic base of the nation. Henry (2017) posit that insurgency was very active in 2009 and decimated numerous communities, destroyed food crops, killed cows and forced inhabitants to flee to protective camps. This insurgency if not immediately curtailed would have damming consequences on the agricultural projects in North East Geo-Political Zone.

Daily Trust Newspaper (2016) reviewed the World Bank Support for agricultural sector in North East Nigeria with 50 million dollars, the money was meant for the restoration of the agricultural livelihood of Fadama beneficiaries in the North East. According to the Task Team Leader of the Fadama III Project, disclosed that the support and programme would last till December, 2021. This support base is for the entire six states that make up the zone. Although the programme is attached with counterparts' funds of 20 million naira each from the states. The programme is to reach out to 24,000 households. The programme is also to ensure that farmers in this area are back to farms.

The United Nation Development Programme also have agricultural Development interest in the North East Zone of Nigeria. The UNDP knowing fully well that the area is bedeviled with incessant conflicts which have displaced thousands of people. The United Nation through UNDP are supporting farmers with necessary agricultural inputs that would help them restart their livelihoods after protracted conflicts. According to UNDP (2016) report that, six thousand farmers have been supported with seeds, fertilizer and insecticide in Borno State. Though Borno State is used as a pilot study, but the programme is for the six states that make up the zone. The objective of the programme is to support mainly displaced and returning farmers to meet their needs, including agricultural input.

The Japanese government is at the forefront of providing succor to the people of North East Nigeria. The Japanese project was targeted at providing agricultural inputs for the planting season, farming, irrigation facilities, livestock farming and fishery to about 1,700 farmers in three states of Borno, Adamawa and Yobe. The International Fund for Agricultural Development (IFAD), an International Financial Institution and Specialized agency of United Nations and committed to eradicating poverty and hunger in rural areas, is interested in agricultural development programmes in North East. IFAD (2016) has invested much in Rural Development Community Based Agricultural Rural Development Programme. Though 
the agricultural programme by IFAD was launched in the eight northern states in Nigeria where poverty is widespread. Borno and Yobe States in the North East are beneficiaries of IFAD programmes which concern is to improve agricultural practices and resolves conflicts between farmers and pastoralists and intensify crop and livestock production. The programme is also to develop and upgrade safe water supply, environmental sanitation, irrigation and health and education facilities.

The Nigerian government too is not resting in formulating and implementing agricultural programmes in North East. Premium Times (2014) reported that, the Nigerian government registered 2.5 million farmers in North East, the Director in the Federal Ministry of Agriculture and Rural Development made this known to the public. He directed that 21.5 million registered farmers are beneficiaries of the fertilizer programme. The Nigerian government through the Ministry of Agriculture and Rural Development provided 13,000 tons of improved seeds to farmers. Also all the farm inputs provided to farmers followed the 2.5 percent counterpart funds paid by each of the six states in the zone (Premium Time, 2014). The Ministry of Agriculture and Natural Resources in Taraba State embraced the Agricultural Transformation Agenda (ATA) of the Federal Government. The agenda is to address challenges in the agricultural sector and then boost agriculture in Nigeria. According to NAN (2014) the introduction of the Growth Enhancement Support Scheme (GES) or Ewallet of the fertilizer distribution has recorded remarkable achievement in North East. This policy has eliminated middlemen in the process of fertilizer diction thereby allowing inputs to reach the target farmers directly.

\subsection{Effects of Communal Conflicts on the Implementation of the Agricultural Development Programmes in North East}

It is a well-known fact that policy implementation cannot take place in an environment bereft of peace. The various agricultural development programmes for the North-East Geo-Political Zone are to attract well-meaning development to the area, reduce poverty and human capital development. But with intense conflict the programmes would end up as a pipe dream. In line with Peterson (2010), Nigeria, Ethiopia and Sudan were among the six countries that experienced the highest level of casualties in communal conflicts. Other three are Somalia, Kenya and Uganda. Nigeria with the highest number of communal conflicts saw the third highest number of deaths. Death is one of the terrible effects of communal conflicts. These are young and energetic people who would have contributed to the implementation of these agricultural programmes and play key role to the economic and political development of the North-East Geo-Political Zone and Nigeria. Apart from death those who happened to survived most of the conflicts are usually victims of deformities: they could be deaf, blind and physically challenged as a result of the sophisticated weapons used in the conflict. This is the case in Borno, Taraba, Bauchi, Yobe and Adamawa. Though the Federal Government of Nigeria has made medical facilities available for these victims of conflicts. People who are physically challenged may not be able to carry out some rigorous agricultural programmes that are geared towards their development. These people are to drive the implementation programmes with appropriate structures and funds. All the agricultural development programmes for the North-East are quite commendable and geared towards the development of the area. With the protracted conflicts in the area, it is a source of concern to both the Nigerian government and the international community. Some of the agricultural developmental programmes are sponsored by foreign governments, the United Nations and the government of Nigeria. The implementation need to be conducted in an atmosphere of peace. There is no policy that can thrive in an environment characterized with violence and animosity. These various agricultural development programmes from the objectives are targeted towards human capital development, food security, infrastructural development and the overall economy of the area. These programmes are supposed to undergo the policy processes of formulation, implementation and evaluation, but with the conflict the agricultural programmes implementation is bound to fail. The North East Zone is very strategic to the economic and political development of Nigeria. For instance, the area is a food producing region and also a movement point for livestock moving to different locations (Henry, 2017). North east has link roads to Chad, Niger and Cameroon. The strategic location of the area is key to the development of the programmes. But the activities of Boko Haram insurgency have caused enormous devastation to agricultural development programmes and the destruction of livelihood of the people. For Awodola and Oboshi (2015), the outbreak of Boko Haram conflict, Maiduguri, which is the capital of Borno State has been threatened by food insecurity. Also Maiduguri used to be a shipping part and leading commercial area of the boarders' region of Nigeria with Cameroon, Chad and Niger. It was also a link for agricultural products for the twenty-seven local government areas of Borno State (Awodola and Oboshi, 2015).

Similarly, Yobe state is not free from the onslaught of Boko-Haram attacks, schools and other infrastructural facilities that would have made life easy for the people of the state are target to the insurgents.

Communal conflicts have caused the displacement of so many persons in the area. The North East Nigeria situation Report (2016) indicated that 2.4 million people are internally displaced in North East owing to conflicts. People who are facing displacement cannot engage in agricultural development programs of any such since they are gasping for survival and the mercy and care of the government, Non-Governmental Organizations and public spirited persons with humanitarian consciousness. Victims of displacement face serious trauma, emotionally and psychologically unbalanced.

To further worsen the implementation of the programs, the foreign government, Non-Governmental Organizations, United Nations and the Nigerian government that are behind these large scale agricultural development programs would stop any attempt to invest further in the programs because of the communal conflicts investing in such bloody terrain amount to waste of resources. In economics study, investors do not invest in war prone areas and such place is a breeding ground for the escalation of poverty. Food shortage is likely to abound in North-East Nigeria, since the various agricultural programs cannot be implemented by the people due to the crises in the domain. Companies that deal with agricultural products for manufacturing would face serious problem and lack of materials to effectively and efficiently carryout its organizational goals, thus creating room for retrenchments and further add to the worsening unemployment crisis in Nigeria. In an atmosphere of unemployment social problems such as armed robbery, prostitution, kidnapping and 
petty crimes are bound to rise beyond proportion. The people in this harsh environment are ready made materials for Boko-Haram membership or any other deadly groups that are capable of causing more harm and prolong the conflict which the government is managing to resolve.

The effect of the conflict can cause mistrust among warring communities, religious groups, farmers and herders among others to become perpetual enemy and this enmity would affect the implementation of the agricultural development programmes for the zone. For instance, the farmers in Numan in Adamawa State cannot live side by side with Fulani herdsmen in the state considering the conflicts that have caused the death of so many persons from both sides. Communal conflicts weaken the country's unity as the tribes that are involved in conflict would hardly forgive thereby threatening the unity of the country.

\section{Conclusion}

The causes of communal conflicts in Nigeria are clearly known, therefore all hands must be on deck to either put an end or minimize these conflicts since it is part of human nature considering the fact that people come from different backgrounds, tribes, religion and belief system which are likely to contradict one another. Conflict in any society is an ill wind which does no one any good. According to North East Nigeria situation Report (2016) almost 4.5 million people faced acute food insecurity in northeast Nigeria and needed immediate assistance. The calamity resulting from conflict is always huge. Nobody can bring the death back to life. At present, the Federal Government of Nigeria has laid down structures for the rebuilding of North-East Development Zone by establishing the North-East Development Commission. The destruction in this region is quite massive and need urgent attention to bring back life to normalcy and the implementation of the various agricultural development programs in the zone.

\section{Recommendations}

The intervention to stop these protracted conflicts do not lie on the shoulders of government alone. NonGovernmental Organizations (NGOs), Faith Based Organizations (FBOs), Civil Society Groups, Youth Organizations and the Progressives in Nigeria. The first aspect of providing peace in the North East Region of Nigeria is the security agencies to improve and step up on their intelligence gathering techniques. If the security agencies are proactive, they can easily nip conflict in the bud before it escalates. By this the Military, Police, Directorate of State Services (DSS), Nigerian Intelligence Agenda, (NIA) and other security organizations must expand their dragnet and do the needful in closing in on this conflicts that have kept permanent scar on the people minds. The effectiveness of these security outfits into nipping conflict in the bud can be achieved by regular training of personnel on the use of sophisticated and recent ways of curbing violent crimes. The government should grant adequate funds to the security organizations in order for them to meet up their demands of procuring modern equipment to fight any crime.

The various states government in the North East Geo-Political Zone should also aid the security agencies by providing funds and operational facilities for them to avert conflict with all amount of alacrity. The government of Nigeria should create a Ministry for Peace and Conflict Resolution Commission (DCRC). The aim of this organization is to work with neighboring communities that have been on protracted conflict and see how peace and love can be restored in these communities. Workers in this organization must be ready to be posted to remote communities where conflicts are prone and should be under the protection of security agencies. This organization will go a long way into providing peace and conflict resolution in these areas. The organization should have offices in areas where there have been protracted conflicts.

The two-dominant religion in Nigeria, which are Christianity and Islam must preach tolerance, peace, love and unity. The government should be sincere in sanctioning preachers who preach hate. The Ministry of Peace and Conflict Resolution Commission (PCRC) should be part of the already established Ministry for Inter-Religious Affairs in Nigeria so as to settle conflict among the two religious faiths where necessary. Peace must be emphasized and reinforced in places of worship and social gathering.

The justice system of the government should be taken seriously. The judiciary should be open to punish those people who foment trouble in any community. Also, in the event of land disputes, the court should be able to determine and deliver justice to the party concern and then where there are claims and counter claims from parties, the court should have the mandate to confiscate the land give it to the government to avert any crisis.

\section{References}

i. Adejumobi, S. (2001). Citizenship rights and the problem of internal conflict and civil wars in Africa. African Journal of Political Science 6(2): 77-96.

ii. Agbu, 0. (2004). Ethnic Militias and the Threat to Democracy in Post Transition Nigeria, Uppsala: Nordiska African Institute, Research Report No. 127.

iii. Alhassan, U. B. (2013). Herdsmen and farmers conflicts in North-Eastern Nigeria: Causes, repercussions and resolutions. Academic Journal of Interdisciplinary Studies Vol. (20) 5.

iv. Allen, F. and Okeke-Uzodike, U. (2010). Oil politics and conflict in the Niger Delta: A non-killing analysis. African Peace and Conflict Journal 3(2): 32-42.

v. Alozieuwa, S. H. O. (2010). Beyond the Ethno-Religious Theory of Jos Conflict. Africa Peace and Conflict Journal 3(2): 18-31.

vi. Amungwa, A. F. (2011). The Evolution of Conflicts Related to Natural Resource Management in Cameroon. Journal of Human Ecology 45(1): 53-60.

vii. Awodola, B. and Oboshi A. (2015). Terrorism in Northern Nigeria: A threat to food security in Maiduguri. Mediterranean Journal of Social Sciences 6(3): 11-17. 
viii. Ayai, C. O. (2009). Causes of Northern Uganda armed conflict: A Probit Analysis. African Peace and Conflict Journal 2(2): 72-85.

ix. Best, S. G. (2004). 'The Method of Conflict Resolution and Transformation' in Shedrack Gaya Best (ed), Introduction to Peace and Conflict Studies in West Africa: A Reader, Ibadan Spectrum Books Ltd, Nigeria

x. Blanton, R. T. Mason, D. and Athow, B. (2001). Colonial style and post-colonial ethnic conflict in Africa. Journal of Peace Research 38(4): 473-91.

xi. Daily Trust Newspaper (2016).Dailly Trust Nigerian Newspaper

xii. Echiagu, A. O. U. (1998). Yesterday and Tomorrow in Ezaa and Izii's Today, Ibadan: Loyola Book Centre, Nigeria

xiii. Fiki, C. D. \& Lee, B. (2005). 'Conflict Management, Local Capacity Governance, and Inclusive Human Security in North East Nigeria: A Case Study' -Regional Development Dialogue-A Journal of UNRISD, Nagoya Japan.

xiv. Henry, K. K. (2017). 'Boko Haram is Losing, but so is Food Production': Conflict and Food Insecurity in Nigeria and Cameroon', African Development (3) 1977-1996. Council for the Development of Social Science Research in Africa.

xv. Ibaba, I. S. (2007). 'Understanding Oil Company-Community Conflicts in the Niger Delta (Nigeria); Peace and Conflict Studies 14(1): 1-18.

xvi. Ibaba, I. S. (2011). 'Nigeria's Niger Delta: Militia violence, amnesty and energy security' Peace and Conflict Studies 18(1): 44-78.

xvii. Idowu, O. O. W. (1999). 'Citizenship status, statehood problems and political conflict: The case of Nigeria; Nordic Journal of African Studies 8(2); 73-88.

xviii. Imobighe, T. A. Bassey C. \& Asani, J. B. (2002) Conflict and Instability in the Niger Delta: The Warri Case, Ibadan: Spectrum Book Ltd. A Publication of Academic Associates Peace Work (AAPW).

xix. International Fund for Agricultural Development (2016).

xx. Matthew, R. O. (1970). 'Interstate Conflict on Africa: An Overview; International Organization 24(2): 335-60.

xxi. Mortiz, M. (2006), 'The politics of permanent conflict: Farmer-Herder conflicts in Northern Cameroon.Canadian Journal of African Studies 40(1):101-26.

xxii. News Agency of Nigeria (2004).

xxiii. North East Situation Report, August (2016).

xxiv. Obi, C. I., (1999). 'Globalization and environment conflict in Africa. African Journal of Political Science 4(1): 4062.

xxv. Ogban-Iyam, O. (2005). 'Social production and reproduction, societal conflicts and the challenge of democracy in Nigeria' University of Nigeria Journal of Political Economy Vol. 1(1) Pp.1-5.

xxvi. Oji, R. O; Eme, O. I. Nwoba, H. A. (2014). Communal Conflicts in Nigeria: An Examination of Ezillo and EzzaEzillo Conflict of Ebonyi State, (1982-2012).

xxvii. Onwusiribe, C. Nd. Nwaiwu, B. N. and Okpokiri, C. I., (2005). 'Assessment of North Insurgency and Performance of Food Dealers in Abia State, Nigeria' Scientific Papers Series Management, Economic Engineering in Agriculture and Rural Development 15(3): 217-24.

xxviii. Otite, O. \& Albert, O. (1999). 'On Conflicts, their Management, Resolution and Transformation' in Otite Onigu \& Albert Olawale (ed) Community Conflicts in Nigeria, Management Resolution and Transformation, Ibadan: Spectrum Books Ltd.

xxix. Peterson, Therese (2010). Non-State Conflicts 1989-2018: Global and Regional Patterns In: Peterson, Therese and Lotta Themner eds. States in Armed Conflcit 2009, Uppsala Department of Peace and Conflict Research.

xxx. Premium Times, June $7^{\text {th }}$ (2018).

xxxi. Rwantabagu, H. (2001). 'Explaining intra-state conflicts in Africa: The case of Burundi. Journal on World Peace 18(2): 41-53. International

xxxii. Ubi, O. A. (2001). Communal Conflict and Traditional Conflict Resolution, the Ugep/Idomi 1992 Conflict Experience, The Psychologist 3. Pp71-82.

xxxiii. Uhumwangho, S. O. (2011). 'Challenges and solutions to ethno-religious conflicts in Nigeria' Journal of Sustainable Development in Africa 13(5): 10-24.

xxxiv. Ukwo, U., (2003). Ethno-religious conflicts and democratic consolidation in Nigeria. Journal of Modern African Studies 41(1): 11-38.

xxxv. UNDP (2016). UNDP Agricultural Development Project in North East, Nigeria.

xxxvi. Warren, R. C. (1978). The Community in America (3 ${ }^{\text {rd }}$ ed.) Chicago: Rand Macnally College Publishing Company. xxxvii. Wood, A. P. (1993). 'National Resource Conflicts in South-West Ethiopia State, Communities and the Role of the National Conservation Strategy in Search for Sustainable Development Nordic Journal of African Studies 2(2): 83-99. 